УДК 550.382 .4

\title{
ВЛИЯНИЕ СФЕРИЧНОСТИ ЗЕМЛИ НА РЕЗУЛЬТАТЫ АЭРОМАГНИТНЫХ ИЗМЕРЕНИЙ НАД ПЛАТОБАЗАЛЬТАМИ (НА ПРИМЕРЕ НОРИЛЬСКОГО РАЙОНА)
}

\author{
Долгаль Александр Сергеевич, \\ dolga@mi-perm.ru \\ Учреждение Российской академии наук «Горный институт» Уральского отделения РАН, \\ Россия, 620007, г. Пермь, ул. Сибирская, 78-А.
}

\begin{abstract}
Актуальность исследования обусловлена целесообразностью использования модельных представлений, адекватных реальным физико-геологическим условиям, при редуцировании результатов магниторазведки в областях развития платобазальтов. Цель: оценка влияния сферичности Земли на аномальное магнитное поле в условиях резко расчлененного рельефа дневной поверхности, сложенного магматическими горными породами, обладающими повышенной намагниченностью (на практических материалах).

Методы: вычисление поправок за влияние магнитного рельефа местности путем решения прямой задачи магниторазведки для области с радиусом 20 км в двух вариантах: для плоской и шарообразной моделей Земли. Выполнено сопоставление полученных результатов и пространственно-статистический анализ выявленных различий. Предполагалось, что вектор намагничивания слагающих рельеф горных пород направлен по современному геомагнитному полю региона. Переменная по латерали эффективная намагниченность верхней части разреза определялась путем решения линейной обратной задачи магниторазведки.

Результаты. Кратко охарактеризована проблема учета влияния рельефа местности при измерениях магнитного поля над вулканогенными образованиями. На примере материалов крупномасштабной высокоточной аэромагнитной съемки, выполненной в центральной части Норильского рудного района, показаны нелинейные искажения сигнала, связанные с криволинейностью земной поверхности. Амплитуда этих искажений (по модулю) достигает 100-200 нТл и более при сравнительно небольших различиях высотных отметок для разных моделей. Это объясняется высокими значениями вертикального градиента магнитного поля. Выводы. С целью подавления интенсивных аномалий-помех, обусловленных магнитными породами, слагающими верхнюю часть геологического разреза, предложено вычисление топографических поправок с использованием сферической модели Земли. Представляется также перспективным использование статистического подхода, в неявном виде учитывающего форму земной поверхности, для выделения аномалий «рельефной» природы.
\end{abstract}

\section{Ключевые слова:}

Платобазальты, рельеф местности, аэромагнитная съемка, аномалия, топографическая поправка, редуцирование, модель Земли.

\section{Введение}

По сравнению с гравиразведкой, в магниторазведке гораздо слабее проработаны вопросы, касающиеся учета влияния рельефа земной поверхности, сложенного интенсивно намагниченными горными породами, в частности - платобазальтами. Платобазальты, образовавшиеся при линейных излияниях лавы в периоды тектоно-магматической активации платформ, развиты в Сибири, Индостане, в Южной Америке, Южной Африке, Тасмании, Антарктиде и занимают около 5 млн км² $^{2}$ площади континентов [1]. В частности, $250000 \mathrm{kм}^{2}$ территории России занимает трапповое плато Путорана, второе (после плато Декан) по величине в мире, абсолютные отметки высот в пределах которого достигают 1500-1700 м. С процессами платформенного магматизма связаны месторождения цветных и редких металлов [2], железных руд, камнецветного сырья и др. полезных ископаемых, для поиска которых используются геофизические методы, в т. ч. аэромагнитная съемка (AMC).

Характерной особенностью платобазальтов является сложный характер аномального магнитного поля $\Delta T$, обусловленный их высокими магнитными свойствами (эффективная намагниченность $J_{\text {эф }}=3-5 \mathrm{~A} / \mathrm{м} \mathrm{и} \mathrm{более)} \mathrm{и} \mathrm{резко} \mathrm{расчлененным} \mathrm{релье-}$ фом местности, практически полностью исключающий «возможность интерпретации аномалий, связанных с более крупными и глубинными объектами» [3]. Моделирование магнитных аномалийпомех «рельефной» природы осуществляется путем решения прямой задачи магниторазведки [4] для цифровой модели местности (ЦММ) при априорно заданной намагниченности верхней части геологического разреза, как правило, зависящей от координат: $\mathbf{J}_{э \phi}=\mathbf{J}_{э \phi}(x, y)$ [5]. Полученные таким образом значения магнитного поля являются поправками за влияние рельефа местности $\delta T_{\text {р }}$ (топографическими поправками) [5-7]. Физический смысл топографической редукции в гравиразведке и магниторазведке одинаков - приближенное определение аномального эффекта от приповерхностного слоя горных пород с целью его последующего исключения из наблюденных значений поля [8]. Данная редукция может применяться совместно с пересчетом аномального магнитного поля на горизонтальную плоскость [5] или с его аналитическим продолжением на поверхность, конкордантную рельефу земной поверхности («draping» в зарубежной терминологии) $[9,10]$.

При решении прикладных задач в качестве моделей Земли используются: плоскость, шар, эллипсоид вращения, квазигеоид, геоид. Вычисление гравитационных аномалий в редукции Буге может базироваться как на плоском [11], так и на сферическом [12] представлениях о слое однородных по 
плотности горных пород $\sigma=$ const в окрестностях пункта наблюдений. Установлено, что значения соответствующих поправок $\Delta g_{\mathrm{B}}+\delta g_{\text {р }}$ имеют заметные различия [13]. При вычислении поправок за

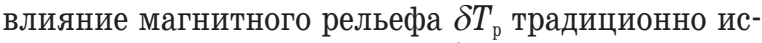
пользуется модель «плоской Земли», геометрические параметры которой характеризует прямоугольная система координат $\Sigma x y z$, а нижней границей ЦММ является горизонтальная поверхность. Такая идеализация физико-геологических реалий на первый взгляд кажется вполне оправданной, т. к. область учитываемого влияния рельефа $S$ в магниторазведке, как правило, меньше, чем в гравиразведке (для средне- и мелкомасштабных гравиметрических съемок радиус области $S$ равен 200 км). Однако влияние формы Земли вносит существенный вклад в амплитуду магнитных аномалий, отвечающих влиянию выходящих на дневную поверхность вулканогенных пород, и его требуется принимать во внимание при разработке методов редуцирования результатов аэромагнитных измерений.

\section{Методика и результаты обработки данных аэромагнитной съемки}

В данной статье будет рассмотрен вопрос о целесообразности использования "сферической» модели Земли при расчете топографических поправок $\delta T_{\text {p }}$ на примере материалов крупномасштабной АMС нового поколения, выполненной НФ ВСЕГЕИ в 2012-2013 гг. в центральной части Норильского рудного района на площади 10000 км². Комплексная аэрогеофизическая съемка выполнялась на самолете Ан-3 по системе прямолинейных широтных маршрутов с обтеканием рельефа, расстояние между маршрутами $250 \mathrm{~m}$, средняя высота полета $H_{\text {пол }}-122$ м. Для измерений магнитного поля использовался аэромагнитометр ГТ-МАГ, укомплектованный квантовым цезиевым датчиком CS-2 фирмы SCINTREX (Канада). Среднеквадратическая погрешность аэромагнитной съемки для поля с горизонтальным градиентом менее 50 нТл/км составила $\pm 0,89$ нТл. Точность определения координат с использованием GPS-технологий составила $\pm 1,55 \mathrm{~m}$.

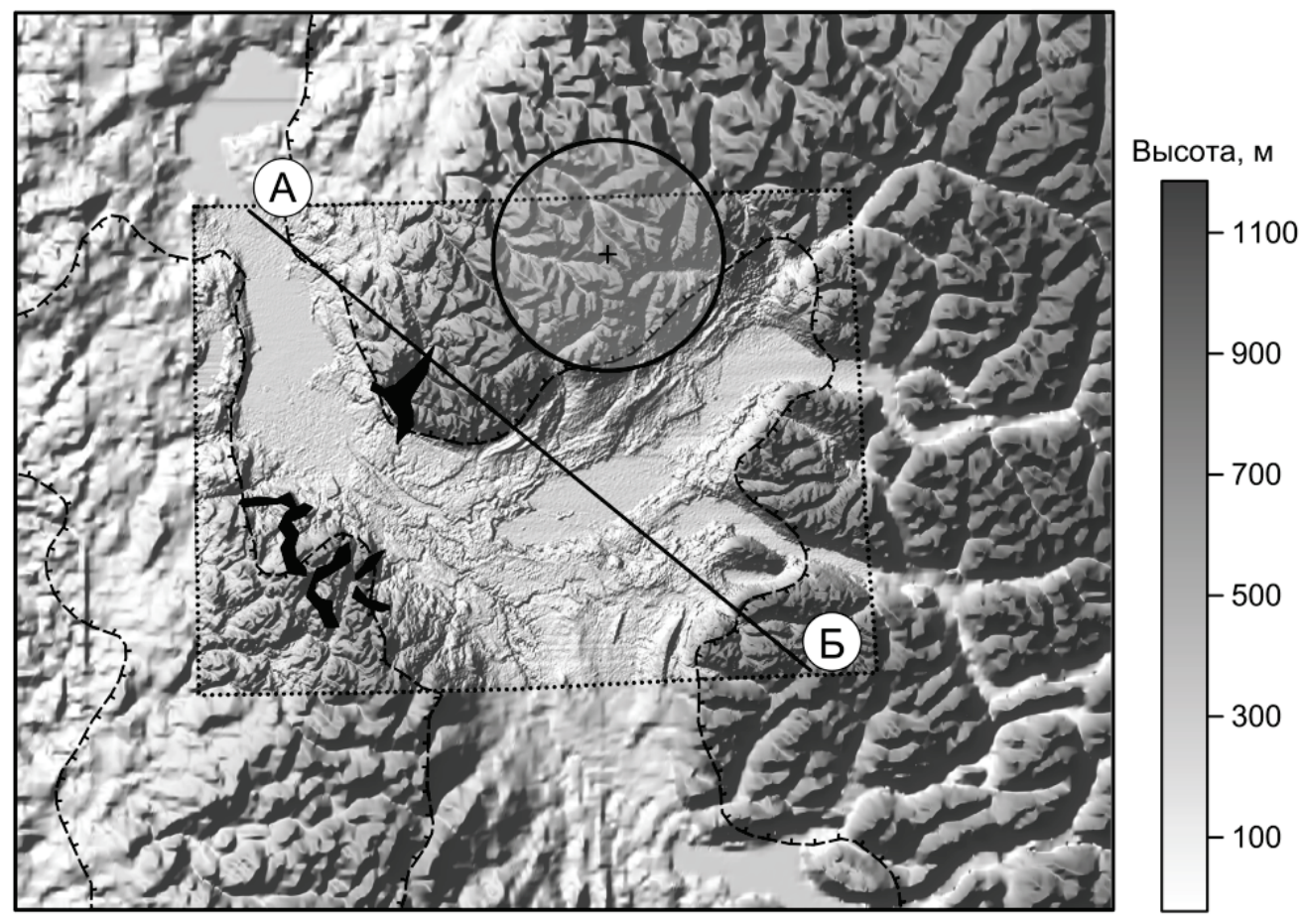

20 KM
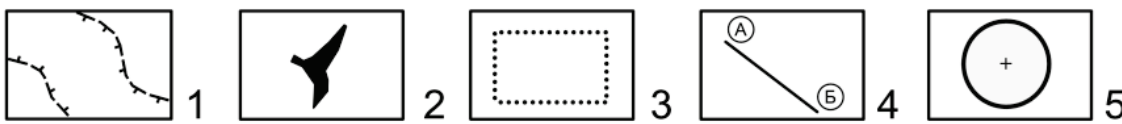

Pис. 1. Карта рельефа дневной поверхности центральной части Норильского района: 1 - границы зон развития вулканогенных образований; 2-рудоносные интрузии; 3 - контур площади аэромагнитной съемки; 4 - профиль АБ; 5 - «палетка» для расчета топографических поправок $\delta T_{\mathrm{p}}$

Fig. 1. Map of the surface relief of the Norilsk region central part: 1 are the boundaries of the zones of development of volcanic formations; 2 are the ore-bearing intrusions; 3 is the contour of aeromagnetic shooting area; 4 is the AB profile; 5 is the "palette» for calculation of topographical corrections $\delta T_{\mathrm{p}}$ 
В пределах площади съемки находятся Хантайско-Рыбнинское поднятие, сложенное преимущественно терригенно-карбонатными, сульфатоностными и терригенными угленосными отложениями палеозоя, а также брахиосинклинали (мульды), выполненные туфобазальтовыми формациями поздней перми и раннего триаса - Норильская, Вологчанская, Хараелахская, Имангдинская, Иконская [14]. Зоны развития вулканогенных пород, занимающие около $48 \%$ рассматриваемой территории, характеризуются преимущественно расчлененным рельефом дневной поверхности с абсолютными отметками высот рельефа до 700-1000 м и более. Широко развиты интрузивные образования триаса, в т. ч. дифференцированные тела габброидов, с которыми связаны крупнейшие в мире платино-медно-никелевые месторождения Норильск 1, Талнахское, Октябрьское (рис. 1). Амплитуда аномального магнитного поля в районе исследований изменяется от -1500 до 2150 нТл, отмечается пространственная корреляция интенсивных положительных аномалий $\Delta T$ с наиболее приподнятыми участками в пределах трапповых мульд. Следует отметить, что интенсивность локальных магнитных аномалий $\Delta T$, обусловленных дифференцированными интрузиями, как правило, не превышает 50-100 нТл. Выделение аномалий «рудной» природы в пределах трапповых мульд крайне затруднительно и традиционные методы трансформации магнитного поля для этой цели не дают положительных результатов.

При вычислении топографических поправок $\delta T_{\text {p }}$ в качестве элементарных тел, аппроксимирующих рельеф земной поверхности, использовались вертикальные прямоугольные призмы. Размер оснований призм $100 \times 100$ м отвечал шагу сети ЦММ. Вектор намагниченности $\mathbf{J}_{\text {эф }}$ каждой призмы был направлен по современному магнитному полю $\mathrm{T}_{0}$ региона исследований: наклонение $I=83,5^{\circ}$, склонение $D=17,6^{\circ}$. Апликаты верхних оснований призм отвечали абсолютным отметкам высот $H$ земной поверхности, нижние основания располагались на уровне $z=0$. Путем векторизации крупномасштабных топографических карт была сформирована ЦММ, имеющая площадь 30500 кв. км, представляющая собой прямоугольную матрицу высот Н, размером 1581 строка, 1931 столбец. Полученное в процессе АMC аномальное магнитное поле было представлено в виде матрицы $\Delta \mathrm{T}$ размером 911 столбцов, 1229 строк. С использованием данных радиовысотомера была сформирована матрица абсолютных отметок точек измерений $\mathbf{H}_{\text {пол. }}$.

С целью оценки размеров области $S$ учитываемого влияния рельефа ( «палетки»), имеющей форму круга с радиусом $R$, применялось вычисление топографических поправок $\delta T_{\text {р }}$ при последовательно увеличивающихся значениях $R: 2 \leq R \leq 25$, км. Определялась энергия $E^{2}$ магнитных аномалий для каждой из результативных матриц $\delta \mathrm{T}_{\mathrm{p}}$. Выход функции $f=E^{2}(R)$ на асимптоту послужил критери- ем для выбора скользящего окна размером $R_{\text {опт }}=20$ км для дальнейших расчетов.

Для приближенной оценки петромагнитных характеристик верхней части геологического разреза использовались материалы ранее выполненной аэромагнитной съемки масштаба 1:100000 на постоянной барометрической высоте 2400 м. Величина модуля намагниченности $J_{\text {эф }}=J_{\text {эф }}(x, y)$ слагающих рельеф горных пород определялась путем решения линейной обратной задачи магниторазведки. Изучаемый объем геологической среды для территории 30500 кв. км (площадь AMC-25 и зона обрамления, необходимая для расчета топографических поправок) был представлен в виде прямоугольных блоков с размерами в плане $1000 \times 1000$ м, достигнутая невязка наблюденного и модельного полей в евклидовой метрике составила $\sim 0,7$ нТл. Расчетные значения намагниченности $J_{\text {эф }}$ вулканогенных образований изменяются от 0,07 до 4,22 A/м, что согласуется с имеющимися петрофизическими данными.

Амплитуда поправок за влияние рельефа изменяется в диапазоне от -620 до 822 нТл, наибольшие положительные значения $\delta T_{\text {р }}$ отвечают водораздельным зонам развития молодых базальтов с высокими содержаниями ферромагнитных минералов, над долинами рек отмечаются линейные зоны отрицательных значений $\delta T_{\mathrm{p}}$. В редуцированном (полученном после ввода топографических поправок) магнитном поле $\Delta T_{\text {ред }}$ и его трансформантах нашли свое отражение почти все известные медно-никелевые месторождения Норильского района. В результате подавления аномалий-помех, созданных верхней частью разреза, была получена принципиально новая геологическая информация, которую можно использовать для решения прогнозно-поисковых задач.

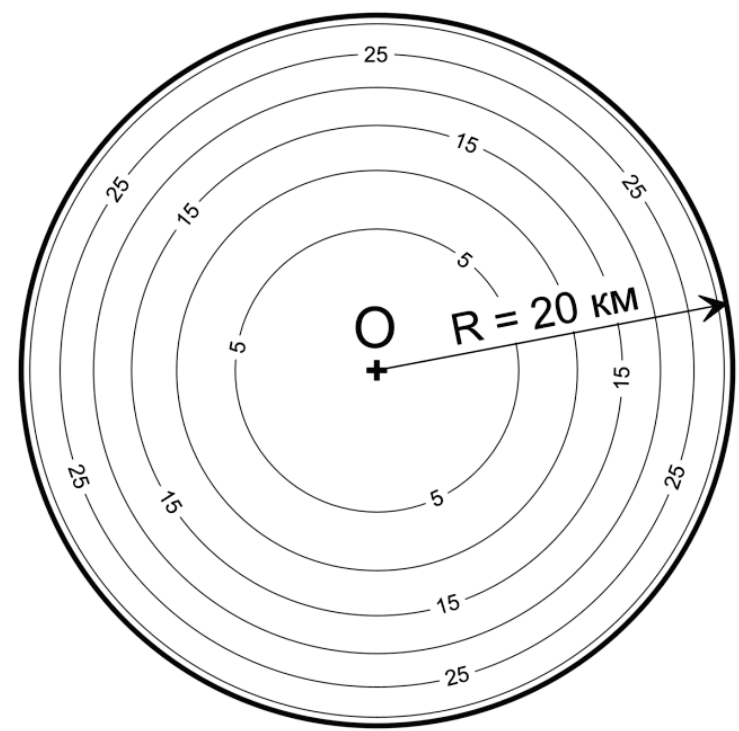

Pис. 2. Изолинии разности высот «плоской» и «сферической» моделей Земли в пределах области S («палетки»), м

Fig. 2. Isolines of the height difference between "flat» and «spherical» models of the Earth within the area $S$ («palettes»), $m$ 
Весь процесс обработки данных, как было сказано выше, выполнялся в рамках модели «плоской» Земли - нижней границей ЦММ являлась горизонтальная плоскость (уровенная поверхность $z=0$, относительно которой осуществлялся отсчет высот рельефа $H$ ). Более точным приближением к форме нашей планеты является шар с радиусом $r=6371$ км - «сферическая» модель Земли. Рассмотрим случай, когда поверхности «плоской» и «сферической» моделей Земли соприкасаются в центре $O$ области $S$ «палетки». Разность высот $\Delta z$ для этих моделей в произвольно выбранной точке с координатами $(x, y)$ в проекции Гаусса-Крюгера определяется по формуле

$$
\Delta z=r-\sqrt{r^{2}-x^{2}-y^{2}}
$$

и на внешней границе области $S$ составляет 231,4 м (рис. 2). Можно осуществить изгиб уровенной поверхности $H=0$, в вычислительном плане сводящийся к корректировке высот $H$ в пределах «палетки», в соответствии с параметром $\Delta z$, без изменения планового положения точек ЦММ. Таким образом, центры нижних оснований моделирующих рельеф призм теперь будут находиться на поверхности сфе-
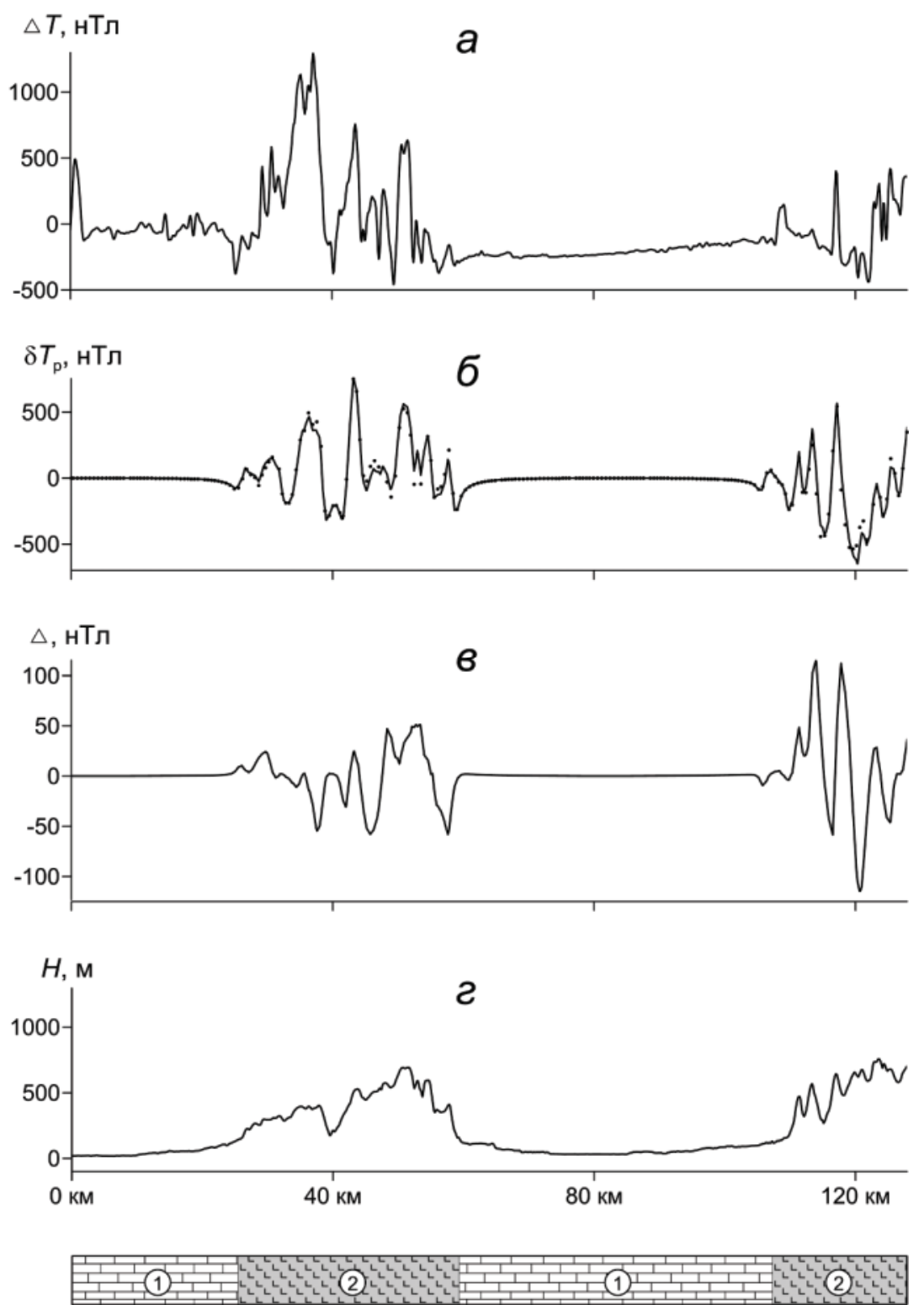

Рис. 3. Графики геолого-геофизических паралетров по профилю АБ: а) аномальное магнитное поле $\triangle T$; б) топографические поправки $\delta T_{\mathrm{p}}$ для «плоской» (сплошная линия) и для сферической (точки) Зелли; в) разность $\Delta$ топографических поправок для «плоской» и «сферической» Земли; г) рельеф дневной поверхности: 1 - осадочные отложения; 2 - вулканогенные образования

Fig. 3. Graphs of geological and geophysical parameters along the AB profile: a) anomalous magnetic field $\Delta T$; $\sigma$ ) topographic corrections $\delta T_{\mathrm{p}}$ for the «flat» (solid line) and for the spherical (point) of the Earth; 8 ) difference $\Delta$ of topographic corrections for the «flat 2 and «spherical» Earth; г) surface topography: 1 - sediment; 2 - volcanogenic formations 
рического сегмента высотой 31,4 м. Этот подход был реализован при втором цикле вычислений поправок за влияние магнитного рельефа, отвечающих «сферической» модели Земли.

Рассмотрим различия в значениях $\delta T_{\text {р }}$ для разных моделей Земли на примере профиля АБ, пересекающего южную часть Хараелахской мульды (рис. 1), с перепадом высот рельефа 740 м (рис. 3, г). Аномальное магнитное поле $\Delta T$ по профилю изменяется от - 465 до 1296 нТл (рис. $3, a)$; размах значений топографических поправок составляет $\sim 400$ нТл; графики $\delta T_{\text {р }}$ для двух алгоритмов расчета, в представленном на рис. 3 , б вертикальном масштабе, очень близки между собой. Однако разность $\Delta$ топографических поправок для «плоской» и «сферической» Земли изменяется в диапазоне $[-115,115]$ нТл, при среднем значении $m=0,8$ нТл и среднеквадратическом отклонении $\delta= \pm 25,6$ нТл (рис. 3, в).

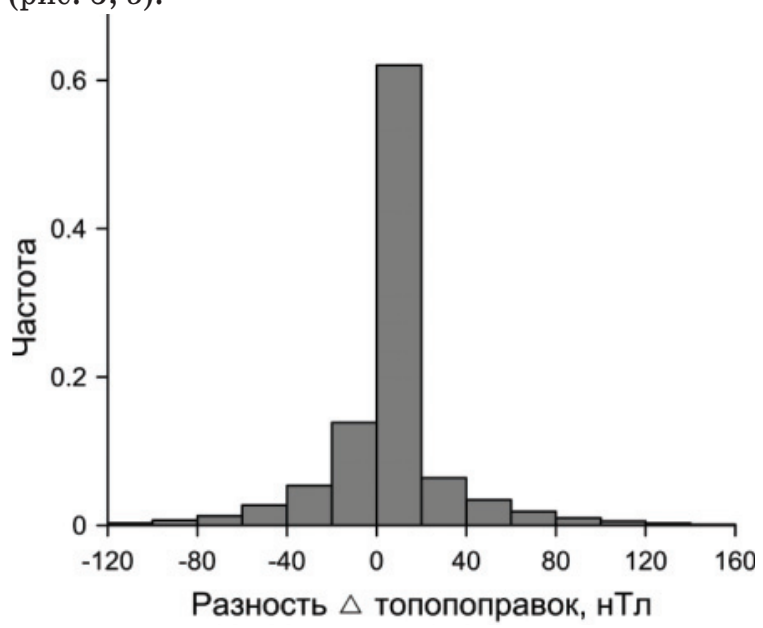

Pис. 4. Гистогралла разности $\Delta$ поправок $\delta T_{\mathrm{p}}$ за влияние релье фа местности в пределах иентральной части Норильского района

Fig. 4. Histogram of the difference $\Delta$ of corrections $\delta T_{\mathrm{p}}$ for the influence of the terrain in the central part of the Norilsk region

Для всей площади АМС этот диапазон еще шире и составляет $[-252,251]$ нТл, при $m=2,6$ нТл и $\delta= \pm 29,7$ нТл (рис. 4). Максимальная величина $\Delta$ может достигать $\sim 16,5 \%$ от наибольшего (по модулю) значения поправки $\delta T_{\mathrm{p}}^{\text {сФ }}$ для сферической Земли и примерно в 2 раза превышает аномальный эффект от рудоносных интрузий. Среднее значение квадрата амплитуды (энергия) для разности $\Delta$ топографических поправок составляет $\sim 2,3 \%$ от средней энергии $\delta T_{\mathrm{p}}^{\mathrm{C \Phi}}$.

\section{СПИСОК ЛИТЕРАТУРЫ}

1. Арискин А.А. Формации платобазальтов Земли. Океанические плато и континентальные траппы. Лекция № 17. URL: http://wiki.web.ru/images/b/b0/Magmatic_Petrology_Lec11_ 2013.pdf (дата обращения 17.07.2018).

2. Krivolutskaya N.A. Siberian Traps and Pt-Cu-Ni deposits in the Noril'sk area. - Springer, 2016. - 361 p.
Следовательно, пренебрежение сферичностью Земли в данных физико-геологических условиях приводит к весьма заметным высокочастотным искажениям магнитного поля $\Delta T_{\text {ред }}$. Эти искажения обусловлены высокими значениями вертикального градиента $d\left(\delta T_{\mathrm{p}}\right) / d z$ над платобазальтами, достигающими 5-8 нТл/м и более. Градиент магнитного поля может быть как положительным, так и отрицательным по знаку.

\section{Заключение}

Представленные результаты приводят к выводу о необходимости использования представлений o «сферической» (а в дальнейшем - «эллипсоидальной») Земле при разработке компьютерных технологий учета влияния магнитного рельефа местности, базирующихся на решении прямой задачи магниторазведки (в т. ч. с использованием сферических аппроксимирующих тел). Это полностью согласуется с современными тенденциями в редуцировании данных гравиметрических съемок [15] и обеспечивается вычислительными возможностями современных компьютеров [16]. Еще одним перспективным направлением исследований является развитие статистических приемов определения топографических поправок $\delta T_{\text {p }}$, в частности - использующих метод EMD (эмпирической модовой декомпозиции) $[17,18]$. Применение статистических методов целесообразно при обработке фондовых материалов аэромагнитных съемок, характеризующихся низкой точностью плановой привязки съемочных маршрутов и отсутствием данных о фактических высотах полетов. В этом случае учет криволинейной формы земной поверхности будет происходить в неявном виде. При выполнении АMC на больших территориях $[19,19]$ «сферическая» модель Земли может повысить достоверность результатов количественной интерпретации полученных материалов.

Автор выражает глубокую благодарность директору НФ ВСЕГЕИ канд. геол.-минерал. наук Ф.Д. Лазареву и главному геофизику НФ ВСЕГЕИ П.В. Кирплюку, благодаря которыл был апробирован в производственных объёмах ввод поправок за влияние лагнитного рельефа лестности в результаты высокоточных аэролагнитных наблюдений. Полученные результаты включены в отчет по объекту «Опережающие геофизические исследования в пределах Хантайско-Рыбнинского поднятия с иелью оценки перспектив медно-никелевого оруденения».

Работа выполнена при поддержке РФФИ (проекты № 19-05-00654 A, 18-05-70094 «Ресурсы Арктики»).

3. Методические рекомендации по средне- и крупномасштабной магнитной картографии. - Л.: НПО «Рудгеофизика», 1990. $84 \mathrm{c}$.

4. Автеньев Г.К., Ерофеев Л.Я., Сысоев А.Т. Аналитическая связь между магнитными аномалиями и формой рельефа местности // Известия Томского политехнического института. 1976. - T. 260. - C. $63-67$. 
5. Долгаль А.С. Магниторазведка: компьютерные технологии учета влияния рельефа местности. - Пермь: Перм. гос. нац. исслед. ун-т, 2014. - 92 с.

6. Иванов В.К. Учет влияния рельефа при магниторазведке // Разведка и охрана недр. - 1977. - № 5. - С. 42-47.

7. Ахметов Е.М., Нусипов Е.Н., Сологуб Т.В. Учет влияния рельефа в аэромагниторазведке // Развитие методов обработки и интерпретации геофизической информации. - Алма-Ата: Казахский политех-кий ин-тут, 1991. - С. 60-70.

8. Ремпель Г.Г. Актуальные вопросы методики введения поправок, связанных с рельефом местности, в данные гравиразведки и магниторазведки // Изв. АН СССР. Сер. Физика Земли. 1980. - № 12. - C. $75-89$.

9. Pilkington M., Thurston J.B. Draping corrections for aeromagnetic data: line-versus grid-based approaches // Exploration Geophysics. - 2001. - V. 32. - № 2. - P. 95-101.

10. Cowan D., Gordon C. Drape-related problems in aeromagnetic surveys: the need for tight-drape surveys // Exploration Geophysics. - 2003. - V. 34. - № 1. - P. 87-92.

11. Гравиразведка: справочник геофизика / под ред. Е.А. Мудрецовой, К.Е. Веселова. - М.: Недра, 1990. - 607 с.

12. LaFehr, T.R., Nabighian, M.N. Fundamentals of Gravity Exploration. - Tulsa: SEG, 2012. $218 \mathrm{p}$.

13. Бычков С.Г., Долгаль А.С., Симанов А.А. Вычисление аномалий силы тяжести при высокоточных гравиметрических съемках. - Пермь: Ур0 РАН, 2015. - 142 с.

14. Геология и рудоносность Норильского района / О.А. Дюжиков, В.В. Дистлер, Б.М. Струнин и др. - М.: Наука, 1988. $498 \mathrm{c}$.
15. New standards for reducing gravity data: the North American gravity database / W.J. Hinze, C. Aiken, J. Brozena, B. Coakley, D. Dater, G. Flanagan, R. Forsberg, T.G. Hildenbrand, R. Keller, J. Kellogg, R. Kucks, X. Li, A. Mainville, R. Morin, M. Pilkington, D. Plouff, D. Ravat, D. Roman, J. Urrutia-Fucugauchi, M. Veronneau, M. Webring, D. Winester // Geophysics. 2005. - V. 70. - № 4. - P. 25-32.

16. Старостенко В.И., Пятаков Ю.В., Исаев В.И. Решение прямых задач гравиметрии для сферических аппроксимирующих тел. Тестирование алгоритмов // Известия Томского политехнического университета. - 2013. - Т. 322. - № 1. - С. 35-39.

17. Долгаль А.С., Христенко Л.А. Применение эмпирической модовой декомпозиции при обработке геофизических данных // Известия Томского политехнического университета. Инжиниринг георесурсов. - 2017. - Т. 328. - № 1. - С. 100-108.

18. Dolgal A.S., Muravina 0.M., Hristenko L.A. The reduction of the magnetic field within development areas of the plateaubasalts // Geoinformatics 2017. - Kiev, Ukraine, 15-17 May 2017. 11143_ENG. URL: http://geoinformatics.org.ua/eng/conferences/pages-and-navigation/geoinformatics-2017 (дата обращения 26.12.2018).

19. Rasmussen T.M., Thorning L. Airborne geophysical surveys in Greenland in 1998 // Geology of Greenland Survey Bulletin. 1999. - № 183. - P. 34-38.

20. Cuma M., Zhadanov M.S. Continental-scale joint inversion of Alaska and Yukon gravity and magnetic data // First Break. September 2017. - V. 35. - № 9. - P. 55-62.

Поступила 09.01.2019 2.

\section{Информация об авторах}

Долгаль A.C., доктор физико-математических наук, главный научный сотрудник лаборатории геопотенциальных полей Учреждения Российской академии наук «Горный институт» Уральского отделения РАН. 
UDC 550.382.4

\title{
EFFECT OF EARTH SPHERICITY ON THE RESULTS OF AEROMAGNETIC MEASUREMENTS OVER PLATOBASALTS (ON THE EXAMPLE OF NORILSK REGION)
}

\author{
Alexander S. Dolgal, \\ dolga@mi-perm.ru \\ Mining Institute of the Ural Branch Russian Academy of Sciences,
78-a, Sibirskaya street, Perm, 614007, Russia.
}

The research relevance is caused by the expediency of using model concepts adequate to real physical and geological conditions, while reducing the results of magnetic prospecting in the areas of development of platobasalts.

The aim of the research is to evaluate the influence of the Earth's sphericity on the anomalous magnetic field under conditions of a sharply dissected relief of the day surface which is composed of magmatic mountain rocks that have an increased magnetization (on practical materials).

Methods: calculation of corrections for the influence of magnetic terrain by solving the direct problem of magnetic exploration for a region with a radius of $20 \mathrm{~km}$ in two versions: for flat and spherical models of the Earth. Comparison of the results and spatial-statistical analysis of the identified differences were carried out. It was assumed that the magnetization vector of the rocks forming the relief is directed along the modern geomagnetic field of the region. Variable laterally effective magnetization of the upper part of the section was determined by solving the linear inverse problem of magnetic exploration.

Results. The paper describes briefly the problem of taking into account the influence of the terrain relief in measuring the magnetic field over volcanogenic formations. On the example of materials of a large-scale high-precision aeromagnetic survey, performed in the central part of the Norilsk ore region, the nonlinear signal distortions associated with the curvilinearity of the earth's surface were shown. The amplitude of these distortions (absolute value) reaches 100-200 nT and more, with relatively small differences in elevations for different models. This is due to the high values of the vertical gradient of the magnetic field.

Findings. In order to suppress the intense noise anomalies caused by magnetic rocks composing the upper part of the geological section, the author proposed the calculation of topographic corrections using the spherical model of the Earth. It also seems promising to use a statistical approach, implicitly taking into account the shape of the earth's surface, to isolate anomalies of "relief» nature. A comparison of the results obtained and a spatial-statistical analysis of the revealed differences are performed.

\section{Key words:}

Platobasalts, terrain, aeromagnetic survey, anomaly, topographic correction, reduction, model of the Earth.

The author expresses deep gratitude to the director of the NF VSEGEI Cand.Sc. F.D. Lazarev and the chief geophysicist of the NF VSEGEI P.V. Kirpluk, who tested in production volumes the introduction of corrections on the influence of the magnetic terrain as a result of high-precision aeromagnetic observations. The results obtained are included in the report on the object "Advanced geophysical surveys within the Khantaysk-Rybninsky uplift in order to assess the prospects of copper-nickel mineralization».

The research was supported by the RFBR (projects no. 19-05-00654 A, 18-05-70094 «Arctic Resources»).

\section{REFERENCES}

1. Ariskin A.A. Formatsii platobazaltov Zemli. Okeanicheskie plato $i$ kontinentalnye trappy. Lektsiya № 17 [Formations of the Earth plateau-basalts. Ocean plateaus and continental trapps. Lecture no. 17]. Available at: http://wiki.web.ru/images/b/b0/Magmatic_Petrology_Lec11_2013.pdf_(acessed 17 July 2018).

2. Krivolutskaya N.A. Siberian Traps and Pt-Cu-Ni deposits in the Noril'sk area. Springer, 2016. $361 \mathrm{p}$.

3. Metodicheskie rekomendatsii po sredne- $i$ krupnomasshtabnoy magnitnoy kartografii [Guideline in average- and largescale magnetic mapping]. Leningrad, Rudgeofizika Publ., 1990. 84 p.

4. Avtenev G.K., Erofeev L.Ya., Sysoev A.T. Analiticheskaya svyaz mezhdu magnitnymi anomaliyami i formoy relyefa mestnosti [Analytical relation between magnetic anomalies and local topography]. Izvestiya Tomskogo politekhnicheskogo instituta, 1976, vol. 260, pp. 63-67.

5. Dolgal A.S. Magnitorazvedka: kompyuternye tekhnologii ucheta vliyaniya relyefa mestnosti [Magnetic survey: computer technologies of considering local topography effect]. Perm, Perm State National Research University Press, 2014. 92 p.

6. Ivanov V.K. Uchet vliyaniya relyefa pri magnitorazvedke [Considering relief effect at magnetic survey]. Razvedka i ohrana nedr, 1977, no 5, pp. 42-47.

7. Akhmetov E.M., Nusipov E.N., Sologub T.V. Uchet vliyaniya relyefa $\mathrm{v}$ aeromagnitorazvedke [Considering relief effect in aero- magnetics]. Razvitie metodov obrabotki i interpretatsii geofizicheskoy informatsii [Development of methods of processing and interpreting geophysical information]. Alma-Ata, Kazakhstan Polytechnic Institute Publ., 1991. pp. 60-70.

8. Rempel G.G. Aktualnye voprosy metodiki vvedeniya popravok, svyazannykh s relyefom mestnosti, v dannye gravirazvedki i magnitorazvedki [Relevant issues in technique of corrections, related to location topography, in the data of gravitation prospecting and magnetic survey]. Izv. AN SSSR. Ser. Fizika Zemli, 1980, no. 12, pp. 75-89.

9. Pilkington M., Thurston J.B. Draping corrections for aeromagnetic data: line-versus grid-based approaches. Exploration Geophysics, 2001, vol. 32, no 2, pp. 95-101.

10. Cowan D., Gordon C. Drape-related problems in aeromagnetic surveys: the need for tight-drape surveys. Exploration Geophysics, 2003, vol. 34, no 1, pp. 87-92.

11. Gravirazvedka: spravochnik geofizika [Gravitation prospecting: the reference book of a physicist]. Ed. by E.A. Mudretsova, K.E. Veselov. Moscow, Nedra Publ., 1990. 607 p.

12. LaFehr T.R., Nabighian M.N. Fundamentals of Gravity Exploration. Tulsa, SEG, 2012. 218 p.

13. Bychkov S.G., Dolgal A.S., Simanov A.A. Vychislenie anomaliy sily tyazhesti pri vysokotochnykh gravimetricheskih semkah [Calculations of gravity anomaly at high-accuracy gravimetrical survey]. Perm, UrO RAN Publ., 2015. 142 p. 
14. Dyuzhikov 0.A., Distler V.V., Strunin B.M. Geologiya i rudonosnost Norilskogo rayona [Geology and ore-bearing capacity of Norilsk region]. Moscow, Nauka Publ., 1988. 498 p.

15. Hinze W.J., Aiken C., Brozena J., Coakley B., Dater D., Flanagan G., Forsberg R., Hildenbrand T.G., Keller R., Kellogg J., Kucks R., Li X., Mainville A., Morin R., Pilkington M., Plouff D., Ravat D., Roman D., Urrutia-Fucugauchi J., Veronneau M., Webring M., Winester D. New standards for reducing gravity data: The North American gravity database. Geophysics, 2005, vol. 70, no. 4, pp. 25-32.

16. Starostenko V.I., Pyatakov Yu.V., Isaev V.I. Solving direct gravimetric problems for spherical approximating bodies. Algorithm Testing. Bulletin of the Tomsk Polytechnic University. Geo Assets Engineering, 2013, vol. 322, no. 1, pp. 35-39. In Rus.

17. Dolgal A.S., Hristenko L.A. The application of method of empirical mode decomposition (EMD) in processing of geophysical data. Bulletin of the Tomsk Polytechnic University. Geo Assets Engineering, 2017, vol. 328, no. 1, pp. 100-108. In Rus.
18. Dolgal A.S., Muravina 0.M., Hristenko L.A. The reduction of the magnetic field with-in development areas of the plateaubasalts. $16^{\text {th }}$ International Conference Geoinformatics - Theoretical and Applied Aspect. 2017 Available at: https://www.scopus.com/ inward/record.uri?eid=2-s2.0-85040014521\&partne$\mathrm{rID}=40 \& \mathrm{md} 5=38 \mathrm{ad} 3 \mathrm{~b} 5 \mathrm{bd} 6 \mathrm{~b} 4 \mathrm{~d} 434 \mathrm{eb6f} 4422 \mathrm{dcfa} 41 \mathrm{e} 5$ (accessed 26 December 2018).

19. Rasmussen T.M., Thorning L. Airborne geophysical surveys in Greenland in 1998. Geology of Greenland Survey Bulletin, 1999, no. 183 , pp. 34-38.

20. Cuma M., Zhadanov M.S. Continental-scale joint inversion of Alaska and Yukon gravity and magnetic data. First Break, September 2017, vol. 35, no. 9, pp. 55-62.

Received: 9 January 2019.

\section{Information about the authors}

Alexander S. Dolgal, Dr. Sc., senior researcher, Mining Institute of the Ural Branch Russian Academy of Sciences. 